order that all members may examine them. find his lot cast among such men; it re$A$ fifth and a sixth by-law very clearly and definitely set forth the mode of election, which is confided to the court of censors, who, in presence of the whole college, read aloud the several qualifications, and are then solemnly sworn; whereupon they next retire, and, after deliberation, appear, and report to the college the object of their choice. Now, it must be clear that every one of these laws, to observe which, be it remembered, every member is sworn, has been violated in letter and in spirit. In rain were these legal objections urged against the job. We stand, cries Dr. Jacob, on our resolution. It is replied, that a resolution cannot stand against six by.laws. No matter, is the retort; we take our ground on the resolution, and that resolution cannot be got rid of without " notice of motion." The grand resource of the professors and reform councillors, when at a pinch, was at hand, and a division of noses carried them triumphantly, as usual. But this is not all ; a member does offer the required notice of motion, to move, "at the next meeting of the college, that the resolution aforesaid, being contrary to law, shall be suspended, and that the court of censors be instructed to proceed, in the ordinary method, to the election of a professor of natural philosophy." Will it be credited, that Drs. Jacob and Maunsell, and the rest of them,-all reformers-all members of the council of the association,actually move, by way of amendment on the notice of motion, that they themselves had required, " that such notice be not received by the college," which they carry, as before, by their division of noses! Now, here are men affecting to be liberals and reformers, attached to free institutions, the adrocates of liberty of discussion and freedom of opinion, taking upon themselves the high and responsible office of directing the pre. sent enlightened movement to regenerate the medical profession. Here they present themselves in their true colours, falsifying every one of their former professions; reducing to practice their real sentiments, feelings, and aspirations; virtually carrying out the rankest jobs by the open vio. lation of the laws; exercising the grossest tyranny, by seizing on a free institution, burking the freedom of debate, and by a brate majority determining what only shall be submitted for discussion in a body in which they have usurped a function utterly opposed to the letter and spirit of the charter of incorporation. Reformers of Ireland, are such men to be trusted?

In the remarks which a sense of duty has compelled us to make, it may be scarcely necessary to guard against their being applied to the professor of chemistry himself. We believe Dr. Apjohn's moral and social charaeter place him in as high a scale as his scientific acquirements: we only regret to mains to be seen whether a proper sense of pride will permit him to be made the victim of such jobbing and corrupt patronage.

The real object, however, of the disgraceful but characteristic proceedings we have detailed, was the following:-The school in the college, and in which all these reform councillors are likewise professors, is failing, notwithstanding all the jobbing expedients that have been had recourse to so in. dustriously; and it was thought that the neutral and generally-esteemed character of Dr. Apjohn afforded safe and judicious grounds on which to broach the delicate question of stipendiary endowment of the professorial chairs. The job has been carried in one instance, but we doubt much if, after the storm that has been raised, even the reforming Drs. Jacob and Maunsell will venture to make applications in favour of parties towards whom they certainly entertain more intense, if not more generous, affection. Be this as it may, their real characters stand forth in bold relief, and a voice, trumpet-tongued, demands of the reformers of Ireland, Are they to be trusted?

\title{
NOTE FROM DR. CONQUEST.
}

\section{To the Editor of THE LANCET.}

SrR:-There are two men now in London practising every variety of imposition on the profession. They are so similar in their appearance, that I have little doubt of their relationship ; and they are making their visits to the houses of medical men, at times when they expect to find them from home. Having been entrapped the other day by one of them (and he, I have no doubt, the brother of the one who sent me, a few nights since, on a fruitless errand to Pentonville), I deem it right to put the profession on their guard.

Just as I was leaving my house a few days since, a gentlemanly-looking man, short, stout, about thirty-five years of age, with blue spectacles, and in a pilot coat, drove up to my door in a brown private cabriolet, with a dark bay horse. He gave me his card "Dr.Rogers," and stated that he resided in Welbeck-street, $\mathrm{Ca}$ vendish-square, that he had formerly attended my lectures at St. Bartholomew's Hospital, and also those of Mr. Abernethy, and wishing to obtain permission to examine a book at the British Museum, requested a line or two from me to Sir Henry Ellis to secure that privilege. Recognising in his features an old Bartholomew student, and being pressed for time, I unsuspectingly put my name to a declaration, that I believed him to be a medical man deserving of admission to the reading room of the British Museum.

On his leaving my house he dropped a silk 
handkerchief, having the initials J. C., and these not corresponding with the name on his card ("Dr. Rogers"), awakened my suspicion, now confirmed, by finding no such person in Welbeck-street. Believing, therefore, that he has obtained my signature for some sinister purpose, most probably to lead the unwary to suppose that he is known and recognised by me, I hereby caution the profession and public, and give it as my opinion that the man is an impostor. I am, Sir, your very obedient servant,

\section{J. T. Conquest.}

13, Finsbury-square, Dec. 24, 1840.

\section{VACCINATION IN THE KEIGHLEY UNION.}

\section{To the Editor of The LANCET.}

Sir:-At a meeting of the medical men residing in the Keighley union, beld in Keighley, in the West Riding of York, on Tuesday, the 15th inst., the following resoJutions were passed. I may observe that, since the meeting, the union surgeons (three licentiates of the Hall) have accepted a shilling per case, which was offered by the board of guardians, who at the same time threatened that if they refused the offer, they would unite all the medical offices in to one, and advertise for a young man. I am, Sir, your most obedient servant,

$$
\text { Dec. 19, } 1840 .
$$

Wm. Ainley.

Resolved, 1st,-That the sum of two shillings and sixpence will afford the lowest reasonable remuneration for careful vaccination, and for a correct registration of the cases, and their results.

Resolved, 2nd,-That the board of guardians of the Keighley union have offered the entire privilege of vaccinating, under the provisions of the Vaccination Act, to the union surgeons; which, if accepted by them, the individual members of this meeting will resist such attempt to invade private practice, by continuing to vaccinate the children of the poor gratis, and that they will take every opportunity in their power of making the public aware of such reso. lution.

Dryden and Ainley, Bingley.

Henry Thomas, ditto.

John Mitchell and Son, Keighley.

H. B. Sewell, ditto.

John B. Beck, ditto.

Ed. Soutb Hall, ditto.
MADAME LAFARGE.

\section{To the Editor of The Lancet.}

Sir:-As M. Orfila states that a small portion of arsenic is always present in the bones, is it not possible that it might also be a constituent part of garlic, just the same as silica is found in minute portions in the stalks of corn? This would account for the great resemblance there is between the smell of garlıc and the peculiar odour of arsenical fumes. In this way we need not wonder at arsenic being detected in the stomach of a Frenchman, as the quantity of garlic they eat is well known. At all events, this might lead us to doubt the correctness of the analysis that rested in any degree upon the presence of these fumes. I am, Sir, yours, \&c.

Nov. 26, 1840.

InVESTIGator, W.S.

\section{BOOKS RECEIVED.}

Spinal Diseases; with an improved Plan of Cure. Including what are commonly called Nervons Complaints, and numerous Examples from upwards of One Hundred and Fifty Cases. By John Hey Robertson, M.D. Glasgow: David Robertson; London: Longman and Co. 1841. 8vo. pp. 160.

The Cyclopædia of Domestic Medicine intended for Popular Use; comprising an Account of the Causes, Symptoms, and Methods of Curing Diseases, together with the Diseases of Women and Children and those incident to Warm Climates; with a brief Description of the Medicines in Common Use, and Directions for their Administration. By Keith Imray, M.D. London: Ball, Arnold, and Co. 1840. Paits 1 and 2.

\section{TO CORRESPONDENTS.}

We shall feel pleasure in receiving Mr. Hocken's communications; his paper shall appear in an early Number.

Communications have been received from Mr. George Stilwell; Mr. Burchell; "A Member of the College ;" Mr. Thomas Williams; IIr. Bonney; Mr. Hilll; Mr. Jolnnson; Mr. Smethurst; Mr. Massey; Verax; Dr. Cookson.

Dr. Cookson's reply to the questions of "A Looker-on" shall appear in our next.

We have been unable to find room for the communication of Philalethes this week. It shall appear in our next.

Dr. Blake's letter reached us too late for insertion this week, it shall appear in our next.

Dr. Mackenzie's communication is in the hands of the printer, it shall appear next week. 